\title{
Evaluation of Growth and Yield Attributes of some Lowland Chinese Hybrid Rice (Oryza sativa L.) Varieties in the Coastal Humid Forest Zone of Nigeria.
}

\author{
${ }^{1}$ John Okokoh Shiyam; ${ }^{2}$ Walter Bisong Binang and ${ }^{3}$ Macauley Asim Ittah \\ ${ }^{1,2,3}$ Department of Crop Science University of Calabar, PMB 1115 Calabar, Nigeria
}

\begin{abstract}
Hybrid rice technology has been recognized as a viable approach in increasing the genetic yield. Introducing some hybrid rice varieties in the Nigerian Niger Delta region will ultimately increase national rice production, and ultimately attain self-sufficiency and food security enshrined in the country's National Rice Policy. Field studies were carried out to evaluate the performance of four Chinese hybrid rice varieties (9you 418, 9you138, Xudao151and Xuyou601) in comparison with FARO 15, the best conventional variety in the Cross River rain forest zone of Nigeria. Result obtained showed comparative superiority of FARO 15 to the hybrids in all growth and yield components assessed. FARO 15 was taller $(140 \mathrm{~cm})$ with more productive tillers (11.0), had highest number of 166 spikelets plant ${ }^{-1}, 156.17$ filled grains panicle ${ }^{-1}$, highest filled grains ( $92.17 \%$ ), highest 100-grain weight of $2.63 \mathrm{~g}$ and the highest paddy yield of $5.021 \mathrm{t} \mathrm{ha}^{-1}$. Despite the comparative poor performance of the hybrids, Xudaol51 came close to FARO 15 with grain yield of $2.987 \mathrm{t} \mathrm{ha}{ }^{-1}$, indicating that further agronomic investigations on this promising hybrid could improve its yield substantially and maximize the benefits of hybrid rice cultivation in the region.
\end{abstract}

Keywords: Adaptation, food security, hybrid rice, poverty alleviation, pro-poor farmers.

\section{Introduction.}

Rice (Oryza sativa L.) is one of the most important cereal crops globally and is practically found in all hot climatic regions in the tropical, sub-tropical and warm temperate areas up to $40^{\circ} \mathrm{S}$ and $50^{\circ} \mathrm{N}$ of the equator. The highest yields are obtained in areas lying within $30^{\circ} \mathrm{S}$ and $45^{\circ} \mathrm{N}$ of the equator due to favourable weather conditions.

Rice is cultivated on about 1.77 million ha placing it fifth after sorghum (4.0 million ha), millets (3.5 million ha), Cassava (2.0 million ha) and yam (2.0 million ha) in terms of area of cultivation in Nigeria [1, 2]. It is the leading provider of food calories and it is now the second largest source of food energy in most urban and rural households in many sub-Saharan African countries including Nigeria [3, 4]. Although 240 million people in West Africa rely on rice as a primary source of food energy in their diet, most of this rice is imported at a huge cost of over 1.4 billion USD [5], further worsening the balance of payment difficulties of the country [6]. Self-sufficiency in rice production would improve food security and aid economic development in West African sub-region [7].

The consumption of rice in Nigeria is increasing rapidly due to changes in consumers' preferences, population increase and rapid urbanization. The average Nigerian today consumes about $25 \mathrm{~kg}$ of rice annually, representing $9 \%$ of the total caloric intake [8]. Currently, the country's domestic consumption of rice estimated at 5.5 million metric tonnes is by far higher than the country's annual output of 2.3 million metric tonnes. This consumption level is high and with the high annual consumption growth rate of $5.77 \%$, rice consumption is expected to jump from 5.5 million metric tonnes to 35 million metric tonnes by 2050 [9].

Despite the high level of rice consumption in Nigeria, the annual output of the crop has always lagged behind the demand, thus necessitating the massive importation of the commodity to augment domestic production. In 2011 alone, Nigeria spent a whooping $\$ 35$ billion on rice importation alone, making the country the largest importer of the commodity in the world [10].

In realization of the economic implications of the escalating rice import bills, Nigeria has planned to be self-reliant in rice production in 2015 when a total ban would be slammed on its importation. This is expected to drive diversification of the economy from oil and particularly ensure the national food security, job availability and elimination of extreme poverty among millions of poor and vulnerable Nigerians. China has developed many hybrid rice varieties with superior yield of about 13.9t/ha and important world's rice producers such as Indonesia, Vietnam, Burma, Bangladesh, India, Sri Lanka, Brazil, USA and the Philippines have taken advantage of these hybrid seeds to further increase the genetic yield and Nigeria could do the same to make her dream of becoming self-sufficient in rice production a reality in the nearest future.

Hybrid rice offers higher income opportunities for farmers either through commercial F1 cultivation or hybrid seed production. Since the technology requires more labour than inbred production, more employment 
opportunities can be generated, which in turn contributes to poverty alleviation [11]. Stimulating local rice production through introduction of hybrid rice seeds will not only guarantee high yields, but will also reduce the need to divert valuable foreign currency exchange to rice import. Enhanced local production will also increase accessibility and affordability of food to majority of the people as well as create employment along the value chain and related sections [4].

At the present Nigerian rice farmers who are predominantly small scale operators rely mostly on openpollinated traditional varieties which have low yield potential. The aim of this trial was to evaluate some hybrid rice varieties to boost rice production in the Nigerian Niger Delta region.

\section{Materials And Methods}

This field trial was carried out at the Crop Research Farm of the Department of Crop Science, University of Calabar,Calabar in 2011/2012 cropping season. Calabar is delineated by latitudes $04^{0} 45^{1}$ and $07^{0} 25^{1} \mathrm{E}$ on an altitude of 37 meters above sea level [12]. The site is located in the coastal plains of the Cross River rain forest zone in Southeastern Nigeria. The rainy season which usually spans between March/April to October/November is bimodal with peaks in July and September as well as a short dry spell in August. An average total annual rainfall of about $2000-3000 \mathrm{~mm}$ is common in the area. The mean daily minimum and maximum temperatures are $23^{\circ} \mathrm{C}$ and $33^{\circ} \mathrm{C}$ during most part of the year and the mean relative humidity is between $70-85 \%$. Surface $(0-30 \mathrm{~cm}$ depth) soil samples were randomly taken in the trial plots with a soil auger and composited, processed and analized in the laboratory. Textural analysis of the soil sample by the Hydrometer method [13] showed that the soil was sandy loam with $82.1 \%, 4.9 \%$ silt and $13.0 \%$ clay. Organic carbon, determined by the [14] wet oxidation method was $1.37 \%$, while $\mathrm{pH}$ (soil : water; $1: 2.5$ ) determined by the method of [15] was 4.9. Total $\mathrm{N}$ was determined by the Microkjeldhal method was $0.16 \%$., available Phosphorus, extracted with Bray P1[16] and determined by the Molybdenun Blue Technique of [17] was $46.70 \mathrm{mg} \mathrm{kg}^{-1}$. Exchangeable $\mathrm{K}, \mathrm{Ca}, \mathrm{Mg}$ and $\mathrm{Na}$ contents were extracted with neutral Normal Ammonium acetate solution $\left(1 \mathrm{~N} \mathrm{NH}_{4} \mathrm{OAc}\right.$ at $\left.\mathrm{Ph} 7.0\right)$ solution and determined atomic absorption spectrophotometry, while exchangeable acidity was determined by the potassium chloride titration method of [18]. Values of these cations in the soil were $0.12,0.82,0.49$ and $0.65 \mathrm{meq} 100 \mathrm{~g}^{-1}$ of soil for $\mathrm{Ca}, \mathrm{K}, \mathrm{Na}$ and $\mathrm{Mg}$, respectively and $2.49 \mathrm{meq}$ $100 \mathrm{~g}^{-1}$ of soil for exchangeable acidity. Effective cation exchange capacity (ECEC) of the soil sample was $6.45 \mathrm{mg} \mathrm{kg}^{-1}$.

The land was cleared and tilled manually using a machete and spade respectively. It was then divided into three blocks (replications) each containing five plots measuring $3 \mathrm{~m} \times 3 \mathrm{~m}\left(9 \mathrm{~m}^{2}\right)$ separated by $1.0 \mathrm{~m}$ pathways.

Treatments were four Chinese hybrid rice varieties (9you418, 9you139, Xuyou601 and Xudao151) while FARO15 which is the best open-pollinated variety most commonly grown in the area served as a check. The hybrids have high tillering capacity, strong vigour and good plant type, high yield potential and desirable grain quality. A ground bed nursery was raised on $2^{\text {nd }}$ June2011and 28 days old seedlings were transplanted on $29^{\text {th }}$ June two seedlings per hill and at $20 \mathrm{~cm} \times 20 \mathrm{~cm}$ spacing $\left(500,000\right.$ plants ha $\left.{ }^{-1}\right)$.

Each treatment received a basal application of $60 \mathrm{~kg} \mathrm{P}_{2} \mathrm{O}_{5} \mathrm{ha}^{-1}$ as SSP and $40 \mathrm{~kg} \mathrm{~K}_{2} \mathrm{O}$ ha ${ }^{-1}$ ha as Muriate of potash (MOP) worked into the soil two weeks before transplanting. Nitrogen as Urea at $120 \mathrm{~kg} / \mathrm{ha}$, was split applied at transplanting and at maximum tillering for effectiveness.

Plots were manually weeded as at when due and birds were scared using scare crows during the grain filling period. The relevant data collected to evaluate the performance of the hybrid varieties and the local check were plant height at booting stage, taken from the base of the plant to the collar of the flag leaf [19], number of effective tillers plant ${ }^{-1}$, days to $50 \%$ booting, spikelet count panicle ${ }^{-1}$, number of filled grains panicle ${ }^{-1}$, percentage $(\%)$ filled grains/panicle, 100-grain weight $(\mathrm{g})$, and grain yield $\left(\mathrm{kg}^{-1} \mathrm{ha}\right)$. Data analysis was by analysis of variance (ANOVA) technique and means were tested for significance using Fisher's Least Significance Difference (LSD) at 5\% level of probability [20].

\section{Result And Discussion}

3.1 Vegetative growth. The vegetative growth parameters of the various hybrids and the check variety (FAR015) are shown in TABLE1. There were significant variations in plant height, tillering capacity and reproductive tiller count at harvest. Comparatively, the check variety was tallest followed by variety Xudao 151 while Xuyou618, 9you138 and 9you418 were significantly shorter and did not differ from each other.

Tillering capacity of the hybrid varieties also varied significantly from the check which had significantly $(\mathrm{p}=0.05$ ) highest tiller proliferation, followed by the hybrid variety 9you418 while the other three hybrids (9you138, Xuyou618 and Xudao151) had the lowest tillering potential.

Effective tiller count of the check and hybrid rice varieties also differed significantly with FARO having the highest count, followed by 9you138, 9you418 and least in Xuyou618 and Xudao151.

TABLE 1. Plant height, total and effective tiller count of the hybrid and check rice varieties in Calabar. 
Evaluation of Growth and Yield Attributes of some Lowland Chinese Hybrid Rice (Oryza sativa

\begin{tabular}{lccc}
\hline Rice variety & Plant height $(\mathrm{cm})$ & Total tiller count plant $^{-1}$ & Effective tiller count plant $^{-1}$ \\
\hline 9you418 & 79.00 & 13.60 & 8.77 \\
9you138 & 79.27 & 11.47 & 10.87 \\
Xuyou618 & 71.72 & 10.00 & 7.60 \\
Xudao151 & 94.05 & 9.40 & 6.57 \\
FARO15 & 140.53 & 15.20 & 11.00 \\
LSD $(\mathbf{0 . 0 5})$ & 10.81 & 2.10 & 1.17 \\
\hline
\end{tabular}

3.2. Yield indices and paddy yield

The yield indices (number of spikelets per panicle, number of filled grains per panicle, percent filled grains, 100-grain weight and paddy yield $\mathrm{ha}^{-1}$ ) significantly varied among the hybrids and the check variety (FARO15) as shown in TABLE2. The number of spikelets/panicle and the number of filled grains/panicle were significantly $(\mathrm{p}=0.05)$ highest in FARO15, followed by Xudao151 and similar in all other hybrid varieties evaluated. Percentage filled grain was rather higher in the check variety and in all other hybrid rice varieties than the 9you418 variety. Significant variation also occurred in 100-grain weight among the rice hybrids and between the hybrids and the check variety. FARO15 showed significantly highest seed weight, followed by the Xuyou618 and Xudao151 hybrids and then 9you418 and least in 9you138.

The hybrids and check varieties also showed significant differences in the paddy yield ha ${ }^{-1}$ with FARO15 producing the highest paddy yield followed by Xudao151 while other hybrids had similar and lowest paddy yield.

Table 2: Yield indices and paddy yield of hybrid and check rice varieties in Calabar.

\begin{tabular}{|c|c|c|c|c|c|}
\hline Rice variety & $\begin{array}{l}\text { Spikelets } \\
\text { panicle }^{-1}\end{array}$ & $\begin{array}{l}\text { Filledgrains } \\
\text { panicle }^{-1}\end{array}$ & \% filled grains & $\begin{array}{l}\text { 1000-seed } \\
\text { weight }(\mathrm{g})\end{array}$ & $\begin{array}{l}\text { Paddy yield } \\
\left(\mathrm{t} \mathrm{ha}^{-1}\right)\end{array}$ \\
\hline 9you418 & 79.73 & 60.23 & 75.17 & 22.0 & 1.302 \\
\hline 9 you 138 & 78.20 & 70.63 & 91.06 & 20.7 & 1.775 \\
\hline Xuyou618 & 85.53 & 76.97 & 88.95 & 23.7 & 1.545 \\
\hline Xudao151 & 142.30 & 124.07 & 87.02 & 23.3 & 2.987 \\
\hline $\begin{array}{l}\text { FARO15 } \\
\text { (Check) }\end{array}$ & 166.00 & 156.17 & 92.12 & 26.3 & 5.021 \\
\hline $\operatorname{LSD}(0.05)$ & 16.39 & 21.30 & 10.14 & 0.6 & 0.54 \\
\hline
\end{tabular}

The Chinese hybrid rice varieties studied exhibited differences among themselves and between the check variety (FARO15) in vegetative growth and paddy yield. Comparatively, FARO15 showed superiority over the hybrid varieties in all vegetative and reproductive parameters evaluated. The tallest and shortest hybrids were shorter by $46.5 \mathrm{~cm}$ and $68.8 \mathrm{~cm}$ respectively than FARO 15, a situation typical of hybrid rice varieties. Dwarf nature characteristic of hybrid rice is great advantage in rice as it confers increased resistance to lodging which is a serious problem in tall varieties. Tall varieties are highly susceptible to lodging, particularly at the grain ripening stage. High grain yield loss associated with lodging in rice crop is commonly high in tall rice varieties. All the hybrid varieties were less than one meter tall indicating an agronomic advantage in reducing grain yield loss in the crop due to stem breakage and lodging especially in the lowland rice ecologies.

Tiller proliferation was higher in FARO15 compared with the hybrids which also differed among themselves in this parameter. The hybrids produced more tillers ranging from $9.4-13.6$ tillers plant $^{-1}$ than $^{-1}$ FARO 15. The variation in productive tiller count followed a similar trend with the total number of tillers plant ${ }^{-1}$ produced by each variety. Out of the total number of tillers produced, 5.2\%, 24\%, 27\%, 30\% and 35\% of tillers produced by 9you138, Xuyou618, FARO15, Xudao151 and 9you418 respectively failed to produce panicles and grains. In other words, 9you138 produced the highest $(94.8 \%)$ number of viable tillers, followed by Xuyou618 (76\%), FARO15 (72.4\%), Xudao151 (70\%) and 9you418 (64.5\%). Hybrid varieties have been shown to produce larger total biomass than the open- pollinated varieties but the result of this experiment was contrary in this respect.

In all the yield components assessed, FARO15 was outstanding and superior over all the hybrids evaluated. It produced more spikelets, with more filled grains and higher seed weight and correspondingly higher paddy yield ha ${ }^{-1}$. The growth and yield superiority of FARO15, an open pollinated variety contradicts the established fact that hybrid rice varieties produce larger total biomass and more grains per unit area, with yield superiority of about $15-20 \%$ over self - pollinated or conventional varieties in favourable environmental conditions $[21,22]$. The low paddy yield of the hybrids compared with conventional variety is indicative of the negative heterosis in the parameters among the hybrids under the agroecological conditions of the study area . Failure of expression of hybrid vigor in some rice varieties in certain areas has similarly been reported in Egypt and was attributed to negative heterosis induced by poor adaptability to environmental conditions [23]. 
The poor performance of these hybrid varieties could be a reflection of their poor adaptability under the tropical humid agroecological conditions of the Nigerian rainforest zone or that the level of the nutrients applied did not satisfy the requirement of the hybrids. Furthermore, hybrid rice technology requires high input supply and is usually not profitable in low-input production systems that lack the resources to sustain the technology.

However some of the hybrid varieties particularly Xudao151 showed high promise with grain yield of approximately $60 \%$ of that of the best conventional variety used as a standard for comparison.

Integrating the promising Xuda0151 variety into the farming system could boost rice productivity and provide the basis for national food security as well as generate sustainable income and employment for the propoor small holder farmers who dominate the Nigerian rice sub-sector. Further, intensification of multi-locational varietal agronomic investigations on the hybrids to select the best hybrid rice for different environments could maximize the benefits of hybrid rice cultivation in the country.

\section{Conclusion}

Comparatively, FARO15 showed superiority over the hybrid varieties in all vegetative and reproductive parameters evaluated. However some of the hybrid varieties particularly Xudao151 showed high promise with grain yield of approximately $60 \%$ of that of the best conventional variety used as a standard for comparison. This hybrid variety could be introduced into the farming system to increase the farmers' accessibility to a wide range of high quality planting materials and to boost local production and make Nigeria's bid to become self sufficient in rice production a reality.

\section{References}

[1] [Longtau, S.(2003). Rice production in Nigeria : Multi-agency partnership in West African Agriculture: A literature review of the description of rice production systems in Nigeria. pp98

[2] Adeyeye, V.A. (2010). Strategies for enhancing consumption of locally produced rice in Nigeria.. (Available Online at: http://www.niseronline.org/downloads/ricepodia.pps)

[3] Akande, T. (2003). The Rice Sector in Nigeria. United Nations Crop Project (UNCP) Country Agricultural Project on Trade Liberization in Agricultural Sector and the Environment, Geneva. pp10

[4] AfricaRice (2011). Africa Rice Center (AfricaRice). Lessons from the Rice Crisis; Policies for food security in Africa. Cotonou, Benin. ii $+26 \mathrm{pp}$

[5] WARDA (2005). Rice Trends in the sub-Saharan Africa $3^{\text {rd }}$ ed. West African Rice Development Association, Cotonou. 31p

[6] AfricaRice (2007). Africa Rice Center. Africa RiceTrends:Overview of recent developments in the sub-Saharan Africa rice sector. Africa Rice Center Brief, Cotonou, Benin

[7] Moseley,W.G., Carney, J. and Becker, L (2010). Neoliberal Policy, Rural Livelihoods and Food Security in West Africa: Comparative Study of the Gambia, Cote d'Ivoire and Mali. Proceedings of the National Academy of Science of the United States of America.107(13): 5774-5779

[8] Rice Web (2001). Analysis of rice farming systems in Ogun State and its implications for extension programmes, 1- 102pp. University of Agriculture, Abeokuta, Nigeria.

[9] USDA (2012). Nigeria 2 rice production increase and import raised http://www.fas.usda.gov/pecad2/highlights/2002/03/nigeria rice.htm Agricultural Transformation Agenda (ATA). Paper presented at the $13^{\text {th }}$ National Conference of the Nigerian Association of Agricultural Economists, Obafemi Awolowo University, Ile Ife, Nigeria, September $15^{\text {th }}-27^{\text {th }}, 2012$

[11] Redona, E.D. and Gaspar, M.G.(2001). Hybrid Rice in the Philippines. Proceedings of the $2^{\text {nd }}$ National Workshop on Hybrid Rice. 28-29 November, 2001.Philippines Rice Research Institute, Maligaya, Munoz, Nueva Ecija. 196p

[12] [Shiyam, J.O.,Eyong, M.O., Uko, A.E., Binang, W.B and Ojating, I. (2007). Relative soil fertility improvement efficiency of selected woody species grown on an Ultisol in Calabar, Nigeria. UNISWARES. J.Agric. Sci.\& Tech. 10 (1) : $37-40$

[13] Bouyoucos, G.J. (1962). Hydrometer method improved for making particle size analysis of soil.Agron. J., 54:464-465

[14] Walkey, A and Black, A.I (1963). An examination of the different methods for determining soil organic matter and proposed modification of the Chromic Acid Titration Method. Soil Sci.24: 65-68.

[15] Jackson, M.L (1967). Soil Chemical Analysis. Prentice Hall of India.Pvt Ltd, New Delhi. 498p

[16] Bray, R.H. and Kurtz, L.T. (1945). Determination of total, organic and availableform of phosphorus in soils. Soil Soc. 59: 39-45

[17] [Murphy, J. and Riley, J. (1962). A modified single solution method for determination of phoaphate in natural waters.Anal.Ckem Acta. 27:31-36

[18] Mc Lean, O .E (1982). Soil pH and Lime requirement. In: A.L. Page et al., Methods of soil analysis Part $22^{\text {nd }}$ ed. Agronomy Monograph 9. ASA and SSSA, Madison, Wisconsin.

[19] Emosairue, S.O. and Shiyam J.O. (2006). A compendium of insect pests and natural enemies associated with lowland rice in South Eastern Nigerias. Global Journal of pure and Applied Science, 6(30): $385-387$.

[20] Alika, J.E. (2006). Statistics and Research Methods ( $2^{\text {nd }}$ Edition). AMBIK Press, Benin City, Edo State, Nigeria. vii +363 pp.

[21] Ponnuthurai, S; Vrimani, S.S; Vergara, B.S (1984). Comparative studies on the growth and grain yield of some F1 rice (Oryza sativa L.) hybrids. Philip. J. Crop Sci., 9(3):183 - 193.

[22] He, G.T; Xigaf, Z and Flinn, J.C. (1987). Hybrid Seed Production in Jiangsu Province, China Oryza, $24: 297$ - 312.

[23] Maximos, M.A and Aidy, I.R (1994). Hybrid rice research in Egypt. in: Virmani, S.S (ed). Hybrid Rice Technology: New Developments and Future Prospects. Manila (Philippines). IRRI. p 227-233 